\title{
A Move Towards UNCAT Accession by Malaysia: Challenges and Prospects
}

\author{
ANATI KISAHI \\ ROHAIDA NORDIN
}

\begin{abstract}
The Convention against Torture and Other CAruel, Inhuman or Degrading Treatment or Punishment 1984 (UNCAT) which was drafted after having regard to certain international human rights instruments such as the Universal Declaration of Human Rights 1948 and the International Covenant on Civil and Political Rights 1966, is an instrument specifically drafted to put an absolute prohibition on any forms of torture, and other acts of cruel, inhuman, or degrading treatment or punishment. So far, a majority number of 169 Member States of the United Nations has become State Parties to UNCAT, save for Malaysia and some other minority Member States. Although there have been calls for Malaysia to accede to UNCAT, Malaysia has always argued and maintained its position that it is not ready for accession. Therefore, this manuscript aims: (a) to establish a backdrop to this research by identifying the meaning of "torture" and "other cruel, inhuman or degrading treatment or punishment" and State Parties' duty under UNCAT; (b) to ascertain the challenges and potential for Malaysia in becoming a State Party to UNCAT and accordingly, to recommend the approach to be taken by Malaysia pertaining to UNCAT accession. A legal research methodology via qualitative method that uses primary sources such as international human rights instruments and secondary sources such as academic literatures, is adopted for the purpose of this manuscript.
\end{abstract}

Keywords: Human rights; convention against torture; UNCAT; torture; cruel; inhuman, or degrading treatment or punishment; Malaysia

\section{INTRODUCTION}

The Convention against Torture and Other Cruel, Inhuman or Degrading Treatment or Punishment 1984 (UNCAT) is an international human rights treaty which aims for absolute prohibition on any forms of torture, and other acts of cruel, inhuman, or degrading treatment or punishment (CIDTP) worldwide. It also creates a system to monitor governments and impose upon them accountability. The UNCAT was adopted and opened for signature, ratification and accession by General Assembly resolution 39/46 of 10 December 1984 and came into force on 26 June 1987. UNCAT is divided into a Preamble and three Parts. The Optional Protocol to the Convention against Torture and Other Cruel, Inhuman or Degrading Treatment or Punishment (OPCAT) was adopted on 18 December 2002 at the fifty-seventh session of the General Assembly of the United Nations by resolution $\mathrm{A} / \mathrm{RES} / 57 / 199$ and entered into force on 22 June 2006. Its aim is to prevent torture by establishing places of detention to external scrutiny by independent bodies. ${ }^{1}$

As of 2020, 169 States have become parties to UNCAT. $^{2}$ UNCAT was drafted in accordance with the principles proclaimed in the Charter of the United Nations recognizing freedom, justice and peace in the world and the obligation of States under Article 55 of the United Nations Charter that aims to promote universal respect for, and observance of, human rights and fundamental freedoms. UNCAT was also drafted having regard Article 5 of the Universal Declaration of Human Rights 1948 (UDHR) and Article 7 of the International Covenant on Civil and Political Rights 1966 (ICCPR), both of which provide that no one shall be subjected to torture or to CIDPT. It was also adopted after having regard to the Declaration on the Protection of All Persons from Being Subjected to Torture and Other Cruel, Inhuman or Degrading Treatment or Punishment, adopted by the General Assembly on 9 December $1975 .{ }^{3}$

It is important to note that Malaysia is one of the remaining minority States in the United Nations which have yet to become a State Party to UNCAT. On 26 June 2018, based on a joint press statement published at the Malaysian Bar website, in conjunction with the International Day in Support of Victims of Torture commemorated annually on 26 June, a Coalition comprising of the Human Rights Commission of Malaysia 
(SUHAKAM), Bar Council Malaysia, Amnesty International Malaysia, Lawyers for Liberty (LFL) and Suara Rakyat Malaysia (SUARAM) calls upon the new Government of Malaysia to accede to UNCAT and its Optional Protocol. ${ }^{4}$ Nevertheless, on 8 July 2019, the Government of Malaysia said that since there are many issues that need to be taken into such account mainly on the compatibility of national legislations (be it in the form of civil laws and Syariah laws) with the provisions of UNCAT which would need a review of the relevant legislations, the Government of Malaysia will not be haste into becoming a State Party to UNCAT. ${ }^{5}$ However, at this juncture, there are little research work done to examine the challenges and prospect for Malaysia's accession to $\mathrm{UNCAT}^{6}$, hence the writing of this manuscript.

This manuscript examines the meaning of "torture" and "other cruel, inhuman or degrading treatment or punishment (CIDTP)" under UNCAT and the States' duty under UNCAT. This examination is the pre-requisite to the manuscript's second objective to ascertain the challenges and potential in relation to Malaysia's position in becoming a State Party to UNCAT and accordingly, to recommend (if any) the approach to be taken by Malaysia pertaining to UNCAT accession. This research manuscript adopts a legal research methodology that uses the qualitative method, by using primary sources such as the relevant international human rights instruments and statutes; and secondary sources such as academic literatures.

\section{DEFINING TORTURE AND OTHER CRUEL, INHUMAN OR DEGRADING TREATMENT OR PUNISHMENT}

The word 'torture' derived from the French word torture which originated in the Latin tortura and ultimately deriving from the past participle of torquere meaning 'to twist'. Torture is considered to be a violation of human rights according to Article 5 of the UDHR which provides that no one shall be subjected to torture or to CIDTP. This principle is further reinforced in Article 7 of the ICCPR which provides that no one shall be subjected to torture or to CIDTP. In particular, no one shall be subjected without his free consent to medical or scientific experimentation.
According to Article 1.1 of UNCAT, the term "torture" means "any act by which severe pain or suffering, whether physical or mental, is intentionally inflicted on a person for such purposes as obtaining from him or a third person information or a confession, punishing him for an act he or a third person has committed or is suspected of having committed, or intimidating or coercing him or a third person, or for any reason based on discrimination of any kind, when such pain or suffering is inflicted by or at the instigation of or with the consent or acquiescence of a public official or other person acting in an official capacity. It does not include pain or suffering arising only from, inherent in or incidental to lawful sanctions".

Based on the abovementioned definition, for an act to be deemed as torture under UNCAT, there are several ingredients that need to be satisfied i.e. (i) the suffering that is inflicted be it in the form of severe mental or physical suffering is done intentionally; (ii) such act is done by a public official regardless whether his involvement is direct or indirect in nature; and (iii) such act is done for a specific purpose. ${ }^{8}$ In other words, Article 1.1 simply denotes that torture under UNCAT is any intentional acts that cause severe pain and suffering either physically or mentally, by public officials or other person acting in an official capacity ${ }^{9}$, for the purpose of obtaining information or confession, or intimidation, or punishment, but it does not include pain and suffering caused from lawful sanctions.

What would amount lawful sanctions in this context should be ascertained by referring to the standards available in the respective States as well as at the international level such as the United Nations Standard Minimum Rules for the Treatment of Detainees (which was specifically referred to in the 1975 United Nations Declaration on the Protection of All Persons from Being Subjected to Torture). Thus, would capital and corporal punishment be deemed as lawful sanctions under UNCAT? It has been said that and corporal punishment cannot be justified as lawful sanctions under UNCAT as it would contradict the very purpose and objective of UNCAT as mentioned earlier. ${ }^{10}$

Article 2 of UNCAT provides that each State Party has an obligation to take all necessary measures to prevent acts of torture. This 
includes legislative, administrative and judicial measures, as well as any other measures that may be appropriate. Article 3 of UNCAT sets out the principle of non-refoulement, which requires States not to expel, return or extradite a person to another State if there are substantial grounds for believing that the person would be in danger of being subjected to torture. This basically means that for example, when a person is convicted for an offence in his own State of origin and the punishment he is subjected to is in a form of corporal punishment, and that person is currently in a State which is State Party to UNCAT, the latter State is under the obligation not to return or extradite such person back to the State of origin as such person will have to face corporal punishment which is prohibited under UNCAT.

Today, it is resolved that this exclusion refers to sanctions that are considered lawful as determined by both national and international standards, and should be interpreted narrowly ${ }^{11}$. A narrow interpretation of lawful sanctions protects persons at risk of torture and CIDPT by ensuring that detainees are only subjected to punishments as legitimate exercise of State authority.

UNCAT further provides in Article 2.2 that there are no exceptional circumstances whatsoever that will justify torture, be it a state of war or a threat of war, internal political instability or any other public emergency. This includes any threat of terrorist acts or violent crime as well as armed conflict, international or non-international. The Committee against Torture has expressed its concerns and conviction in the absolute prohibition of torture in that the said Committee has said that even grounds such as in the interest of public security and emergencies, and also religious and traditional grounds cannot be the basis to justify torture and CIDTP. ${ }^{12}$

As the prohibition against torture is absolute, would there not be any circumstances in which torture may be imposed, for instance when it involves crimes of terrorism? This is one of the controversial issues with regard to the infliction of torture particularly when it comes to emergency matters such as terrorism. There is the argument for justification for torture in "ticking bomb" cases - to gather the necessary information. Ticking bomb cases involved cases in which public official inflicted torturous act on victim to gather important information such as details of potential terrorist attacks ${ }^{13}$. The Supreme Court of Israel in the case of Public Committee against Torture in Israel $\mathrm{v}$ the Government of Israel affirmed that the principle that torture is prohibited under international law. However, there might be instances where State authorities could engage in such practices - the so called "tickingtime bomb" 14 . However, the assumption that the objective of inflicting torturous act is merely to gather information is too idealistic. In real life situations other motivations and emotions, such as anger, punishment and the exercise of power, can take over. ${ }^{15}$

The Committee against Torture commented that since the adoption of UNCAT, the nature of absolute ban on the usage of torture and its non-derogable ${ }^{16}$ character has become part of customary international law. The provisions of Article 2 reinforce this peremptory jus cogens norm against torture. ${ }^{17}$ UNCAT also provides that States Parties to UNCAT, under their domestic laws, must make the offence of torture as a punishable offence, taking into account the grave nature as well as the ingredients of torture as provided in Article 1 of the Convention. ${ }^{18}$ Article 5 to 9 of UNCAT simply denotes that the State Parties of UNCAT have the obligation to take action and prosecute the offence of torture regardless whether it is done within or outside the territories of a State and on a non-discrimination basis on the part of the alleged offender. Furthermore, if the State is unable to take such action, that State is required to send or extradite the alleged offender to another State who is able and willing to do so. ${ }^{19}$

Article 16 of UNCAT seems to suggest that other acts of CIDPT are those which do not amount to torture as defined in Article 1 of UNCAT, and such acts are committed by or at the instigation of or with the consent or acquiescence of a public official or other person acting in an official capacity. In practice, the Committee against Torture also has acknowledged that it is difficult to determine the difference between torture and other acts of CIDTP. It has been shown that acts of CIDTP often give rise to torture. Hence, the measures required to prevent torture must be applied to prevent other acts CIDTP as well. Accordingly, the Committee against Torture has considered 
that similar to the character of torture, which is non-derogable and with absolute prohibition, the same applies to the prohibition of other acts of CIDTP. ${ }^{20}$

In order to ascertained on whether torture has occurred, there are several factors that need to be considered i.e. (i) the nature of the act; (ii) the severity of the physical and mental suffering that is inflicted as a result of such act; (iii) the purpose of such act; and (iv) whether such act was done out of a lawful sanction. ${ }^{21}$ As to the nature of the act, a Special Rapporteur's report in 1986 has included a listing of the types of actions that may constitute torture (if other elements of torture is fulfilled). Some of the acts on the list are acts of commission, such as beating, burning, suspension, suffocation, such as by near drowning in water, and exposure to excessive light or noise. There are also acts of omission, such as prolonged denial of rest, sleep, food, sufficient hygiene, or medical assistance, and prolonged isolation and sensory deprivation. Acts of torture may also involve "threats to kill or torture relatives and simulated executions," which are specifically included in the report as examples of acts constituting torture. ${ }^{22}$

The severity of suffering has also been used in order to distinguish whether an act is deemed as torture or whether it will be deemed as other acts of CIDTP. In order to establish whether an act of torture under UNCAT has occurred, such act must result in severe physical or mental pain or suffering. Indeed, for some, "the seriousness of the pain or suffering sets torture apart from other forms of mistreatment". ${ }^{23}$ It is difficult to assess the severity element through objective criteria. Rather, to meet the condition that torture must be severe, it is widely accepted that this is to be interpreted in light of the facts of each case, taking into account the particulars of each victim and the context in which those acts were committed. ${ }^{24}$

Another element is the purpose of such an act in which will determine whether it is an act of torture or an act of cruel, inhuman, or degrading conduct. The Special Rapporteur of the United Nations Commission on Human Rights has indicated that "the requirement of specific purpose seems to be the most decisive criterion which distinguishes torture from cruel or inhuman treatment". In order to establish torture, an act must have been committed intentionally and for a prohibited purpose. UNCAT has provided some illustrations on what kind of purposes will amount acts of torture, and they include to obtain information or confession from a detainee or a third person, to punish them, to intimidate them, or on the basis of any types of discrimination. ${ }^{25}$ Article 1 lists the most commonly found purposes, however, the list is not exhaustive as indicated by the words "for such purposes as" and State are free to add any other purposes to the list. The purpose and intent requirements however do not involve a subjective inquiry into the motivation of the perpetrators, but rather must be objective determinations taking into account all circumstances ${ }^{26}$. UNCAT provides that to constitute torture, an act must be "inflicted by or at the instigation of or with the consent or acquiescence of a public official or other person acting in an official capacity". This means that for acts to constitute torture, the actions must be taken by government officials or with the consent or acquiescence of government officials, be it with a direct or indirect involvement.

At this juncture, it is important to mention that the Committee against Torture has recommended for States to keep the notion of torture separate from the notion of CIDTP. State legislations that criminalized CIDTP must be more explicit as what constitute CIDTP as there is no precise definition of CIDTP in international law $^{27}$.

UNCAT provides that "pain or suffering arising only from, inherent in or incidental to lawful sanctions" does not constitute torture. The Special Rapporteur on Torture has explained that "the Special Rapporteur cannot accept the notion that the administration of such punishments as stoning to death, flogging and amputation-acts which would be unquestionably unlawful in, say, the context of custodial interrogation-can be deemed lawful simply because the punishment has been authorized in a procedurally legitimate manner, i.e. through the sanction of legislation, administrative rules or judicial order. To accept this view would be to accept that any physical punishment, no matter how torturous and cruel, can be considered lawful, as long as the punishment has been duly promulgated under the domestic law of a State". ${ }^{28}$ 


\section{STATES' DUTY UNDER UNCAT}

In relation to a State Party's duties or obligations under UNCAT, they can be divided into two categories i.e. domestic obligations and extraterritorial obligations. There are about 16 provisions under UNCAT which lay down such obligations. The important ones will be illustrated in this sub-heading. In brief, State Parties to UNCAT must ensure and observe their obligations under UNCAT to ensure that any involvement in any torturous acts are made as offences under their domestic legislations according to their severity and grave nature. $^{29}$

Regarding States' domestic obligations under UNCAT, reference can be made to some of the main and relevant provisions under UNCAT as follows:

i. Article 2: States must adopt measures to prevent and prohibit the acts of torture within their territories and such prohibition is non-derogable and absolute in nature.

ii. Article 4: States must ensure that the acts of torture or even attempt to do so are made offences punishable by the domestic criminal laws taking into consideration their grave nature.

iii. Article 5: States must take measure to ensure prosecution of offenders who have done acts of torture.

iv. Article 10: States must ensure that public officials in their official capacity are being given proper training, education and information in relation to the absolute prohibition against torture, and these public officials would include the police and military personnel. It would also extend to those involve in the interrogation and custodial processes.

v. Article 12: States must ensure that investigations are carried out by authorities in a fair manner whenever there are reasonable grounds to believe that acts of torture are committed within their territories.

vi. Article 13: States must ensure that authorities examine the cases complained by individuals who alleged that they have been subjected to any acts of torture and such examination must be carried out in an immediate and fair manner. These individuals and their witnesses are also to be accorded protection and not subjected to torture.

vii. Article 14: States must ensure that victims of acts of torture have access to redress and compensation as well as rehabilitation.

viii. Article 15: States must ensure the exclusion of statements which are obtained from victims as a result of torture to be used as legal evidence except against a person accused of torture as evidence.

ix. Article 19: States must submit reports on measures which they have adopted in ensuring their obligations under UNCAT are being carried out accordingly to the Committee against Torture.

Additionally, reference can be made to some of the main and relevant provisions under
UNCAT regarding State's obligations on non-refoulment, extradition, redress and complain to the Committee against Torture, as follows:

i. Article 3: States are not allowed to return or extradite someone to another State where there are reasonable grounds to believe that that person will be subjected to torture.

ii. Article 8: States must ensure that the offences of torture are made as extraditable offences.

iii. Article 14: States must ensure that victims of acts of torture have access to redress and compensation as well as rehabilitation.

iv. Article 21: A State Party can make complaints against another State Party to the Committee against Torture on the basis that that State Party is not fulfilling its obligations under UNCAT, thus declaring and recognising the Committee against Torture's competence in this matter.

v. Article 22: Individuals of a State Party who claim to be victims of torture, or a person on their behalf, can make complaints against another State Party alleged to have committed torture against that individuals, to the Committee against Torture, but the State Party must have declared and recognised the Committee against Torture's competence in this matter first before it can invoke this provision.

Albeit the provisions under UNCAT which establish obligations for State Parties both in the domestic and extraterritorial domain, there are several weaknesses on the application on UNCAT as well. As aforesaid mentioned in particular on Articles 21 and 22, it is clear that those provisions with regard to inter-State complaint system and individual complaint system respectively, cannot be invoked unless State Parties make a declaration recognising the competency of the Committee against Torture in those matters. Moreover, Article 28 of UNCAT provides that a State Party, upon signature, ratification or accession of UNCAT, can declare that it does not recognise the Committee against Torture's competency on the aspect of requirement to obtain permission from another State Party to investigate an alleged violation of the obligations under UNCAT.

\section{CHALLENGES AND POTENTIAL FOR MALAYSIA IN ACCEDING UNCAT}

The existing and subsisting challenges for Malaysia's accession to UNCAT is discussed in the following paragraphs. ${ }^{30}$

Firstly, the lawmakers in Malaysia need to be convinced that as a State Member to the United Nations General Assembly, it has an 
obligation to assist the United Nations in achieving its objective of establishment ${ }^{31}$. The way in which Malaysia treats its citizens is arguably no longer a matter for its own exclusive determination now that Malaysia is a party to the UN Charter and has accepted the UDHR. ${ }^{32}$ Furthermore, domestic legislation cannot be cited as a justification of any violation of human rights such as torture as, no one claims torture as part of his cultural heritage. Thus, arguably Malaysia should accede to UNCAT and at the same time perform necessary reform to its domestic legislations and policy. This is consistent with Malaysia's official stance that the acts of torture and other acts of CIDTP clearly are violation of human rights principle.

The changes that will need to be made to the domestic legislations will be beneficial for Malaysia and this can only be done by conducting and preparing a comprehensive study while taking into account the diversity aspect of Malaysia in terms of race, religion, social and politics. The dynamic of Malaysian population is the biggest hurdle as consensus will not come easy. In any regards, Malaysia has to have strong political will to ensure effective consultation on necessary legal and policy reform associated with the accession of UNCAT. There must be awareness instilled amongst the public that UNCAT would serve as an instrument that will uphold their fundamental liberties. ${ }^{33}$ UNCAT will be the shield in the battle against the acts of torture and other acts of CIDTP, and efficient method, protection and culpability are the requirements towards the fight against such acts.

The main challenges for Malaysia's accession to UNCAT related to its criminal law framework. The existing criminal laws in Malaysia contain offences which are punishable by corporal punishment including capital punishment such as the death penalty by hanging. If we look into what amounts to torture under UNCAT, it would seem that corporal punishments are prohibited to be inflicted even when those punishments have been legislated to become national laws, based on all that have been discussed in the earlier sub-heading. Examples of corporal punishment in the form of death penalty which still exist in Malaysia are for the offences of murder under section
302 of the Penal Code, waging or attempting to wage war or abetting the waging of war against the Yang di-Pertuan Agong, a Ruler or Yang di-Pertua Negeri under section 121 of the Penal Code and trafficking in dangerous drug under section 39B of the Dangerous Drugs Act 1952. As for other corporal punishment, in Malaysia, offences such as robbery when armed or with attempt to cause death or grievous hurt under section 397 of the Penal Code and criminal breach of trust under section 406 of the Penal Code are punishable with whipping. It is to be noted that based on the definition of torture under UNCAT, Malaysia seems to have a provision which prohibits the use of torture by public officials, for example, sections 330 and 331 of the Penal Code which makes it an offence against whoever voluntarily causes hurt ${ }^{34}$ or grievous hurt ${ }^{35}$ to extort confession or to compel restoration of property, and based on the illustrations of section 330, it applies to public officials such as police officers and revenue officers ${ }^{36}$. However, it is important to emphasize that section 330 and 331 is not specific provisions that criminalize torture as specific crime, separate from other types of offences found in criminal law. In its General Comment No 2, the Committee against Torture emphasized that torture must be made distinct crime as this will "directly advance the Convention's overarching aim". ${ }^{37}$

On the specific issue of capital punishment vis a vis death penalty, the Committee against Torture has always expressed its encouragement upon State Parties to place a moratorium on the imposition of the death penalty and also recommend its abolition. The Committee, at the same time, never said that the imposition of the death penalty itself runs counter with UNCAT, and in fact some State Parties even mention that the existence of the death penalty itself does not contravene with the obligations under UNCAT. ${ }^{38}$ What constitute to be a violation of UNCAT is the situations surrounding to the death penalty itself such as the conditions of the detention and ambiguity for the prisoners awaiting their execution, and the manner the execution is carried out which may amount to torture or other CIDTP. The Committee against Torture has also regarded the use of lethal injections to have potential to inflict 
severe pain and suffering ${ }^{39}$, thus would fall within the perimeters of torture or CIDTP under UNCAT. Therefore, there are concerns that if the use of lethal injections, which most consider as the most humane method of execution is regarded as torture or CIDTP, then there is a possibility that any method of execution would not be acceptable to be used under UNCAT. $^{40}$ It is agreed that there are difficulties in determining what would constitute cruel or inhuman treatment. Looking at the practice amongst State Parties of UNCAT, they refuse to adopt to the notion of "one size fits all" as different societies are different than one another such as Malaysia which is a country that is multicultural and multi religious.

In this regard, the comprehensive study mentioned above must look at which existing practices that constitute torture or CIDTP. One of the early cases in Malaysia that discussed the aspect of prolonged delay in execution of death sentence is the case of Juraimi bin Husin v Lembaga Pengampunan Negeri Pahang \& Ors [2001] 3 MLJ 458. In the said case, the Plaintiff claimed that the prolonged delay in the execution of the death sentence imposed upon him which has caused him to suffer severe mental torture during detention, and the unexplained delay in disposing of his clemency petition have an impact on his constitutional rights guaranteed under Article 5 of the Federal Constitution as such a delay was unjust, unfair and cruel thus depriving the Plaintiff of his right to life. In this case, the plaintiff's clemency petition was not expeditiously dealt with by the Defendant as there was a delay of about 10 months from the date of the clemency petition received to the date it was heard and rejected by the Defendant and no acceptable reasons were given for it. The High Court ruled that "Mercy is not the subject of legal rights. It begins where legal rights end. The death sentence imposed on the plaintiff was constitutionally valid and permissible by law. The legality of a delayed execution cannot be questioned. By its very nature, the prerogative of mercy is not an act susceptible or amendable to judicial review". In this regard, the authors view that although the legality of the death sentence might not strictly tantamount to torture or CIDTP, but unjustified delayed execution may tantamount to CIDTP.
In terms of corporal punishment, the Committee against Torture has taken the approach that all forms of corporal punishment run counter with the provisions of UNCAT. ${ }^{41}$ The Committee against Torture has made an emphasis that State Parties must ensure that there are legislations in placed to express the prohibition on the use of corporal punishment in places like detention centers and other public institutions. In order to ensure the effectiveness of the implementation of such laws, it is important that structures or method for monitoring purposes are formed. ${ }^{42}$

Based on the above discussions, the authors agree that the Malaysian existing legal framework is not compatible to the provisions of UNCAT. However, Malaysia is ready to be a State Party to UNCAT because it has express such intention and stance in various occasions previously ${ }^{43}$. The current domestic legal framework particularly in terms of the imposition of corporal punishment which has been clearly deemed to be in violation of UNCAT and other corporal punishment under the Syariah law may have to be addressed gradually after it accession to the UNCAT. It is recommended for Malaysia, being a dualist country, to review all the criminal offences which are punishable by way of corporal punishment to prove its intention to be bound by the provisions of UNCAT. This position can be different with the imposition of the death penalty itself as the imposition of the death penalty on its own is not a violation of UNCAT. However, in order to be bound by UNCAT, the surrounding circumstances of the death penalty such as the period of detention and the method of execution must be ensured to be consistent with the objective and principles of UNCAT mainly, the prohibition on the use of torture or other CIDTP. Additionally, taking into account the status of Malaysia which is a country that is multi-cultural and multi religious and the legal pluralism that is currently part of Malaysian legal system, ensuring compatibility between domestic laws (civil and Syariah laws) with the provisions of UNCAT remain as the biggest challenge to be addressed by Malaysia in ensuring its compliance to the UNCAT standards. However, it should not be the 
determining factor for Malaysia not to accede to the UNCAT at this juncture.

\section{CONCLUSION}

Becoming a State Party to UNCAT will mean that that the State must take all the necessary measure to ensure that the obligations and duty as stipulated in the provisions of UNCAT, particularly on the absolute prohibition of acts of torture and other CIDTP. Laws must be in place and not only laws, educational facilities and services to educate public officials acting in official capacity, must also be established. All these are necessary for the implementation of UNCAT. All these obligations must be met by State Parties despite of some shortcomings to UNCAT, for instance, the difficulties in distinguishing between torture and other CIDTP as the later will often give rise depending on the nature and gravity of the act. Additionally, a State Party can declare that it does not recognize the Committee against Torture's competency on the aspect of requirement to obtain permission from another State Party to investigate an alleged violation of the obligations under UNCAT.

Arguably, Malaysia's intention to accede to UNCAT and strong political will is sufficient for Malaysia to accede to the UNCAT. However, Malaysia's stance and political will is strongly depending on who form the State government. The popular stance is that Malaysia is a diverse State with numerous backgrounds as to race, religion, ethnicity and culture thus having diverse opinion and stand in relation to the notion of absolute prohibition of acts of torture and other CIDTP, especially in terms of punishment to be imposed on certain offences, thus is not ready to accede to the UNCAT. In any regards, pending accession of the UNCAT by Malaysia, Malaysia is currently on the right track in terms of uphold the principle of prohibition of torture and other CIDTP. This can be seen through sections 330 and 331 of the Penal Code which make it an offence against whoever voluntarily causes hurt to extort confession or to compel restoration of property, which applies to public officials such as police officers and revenue officers; and the ongoing efforts by the State government in improving the surrounding circumstances of the imposition of capital and corporal punishments.

\section{ACKNOWLEDGEMENT}

The authors wish to record their appreciation to Universiti Kebangsaan Malaysia for research grant no GUP/2020/066 financing the final research and publication work of this manuscript.

\section{NOTES}

Secretariat Convention against Torture Initiative. Convention against Torture and Other Cruel, Inhuman or Degrading Treatment or Punishment and Optional Protocol to the Convention against Torture and other Cruel, Inhuman or Degrading Treatment or Punishment. A/RES/57/199.

2 United Nations Treaty Collection. Status of Treaties 9. Convention against Torture and Other Cruel, Inhuman or Degrading Treatment or Punishment. Accessible at ht t p s : / / t e aties.un.org/Pages/View D etails.asp x?s r c = TREATY \& m tdsg_no=IV9\&chapter $=4 \&$ clang=_en (7 January 2020).

Preamble of UNCAT.

4 The Malaysian Bar. Joint Press Statement: The Malaysian Government Must Accede to the UN Convention Against Torture. Accessible at https://www.malaysianbar. org.my/press_statements/joint_press_statement_\% $\%$ c_ the malaysian_government_must_accede_to_the_un convention_against_torture.html (25 November 2019$)$.

Manirajan Ramasamy, 2019. No Rush, Government Says on Ratifying UN Treaty against Torture. Accessible at https://www.freemalaysiatoday.com/category/ nation/2019/07/08/no-rush-govt-says-on-ratifyingun-treaty-against-torture/ (25 November 2019).

6 SUHAKAM, 2016. Report on the Round Table Discussion (RTD) on the Convention against Torture and Other Cruel, Inhuman or Degrading Treatment or Punishment (CAT). Legacy Press, 17 November 2011; Gary Lilienthal, Nehaluddin Ahmad \& Hjh Masnoorani bt $\mathrm{Hj}$ Mohiddin, 2016. The State Obligations and Torture: A Comparative Jurisprudential Analysis. [2016] 2 MLJ clxvii page 2.

Gary Lilienthal, Nehaluddin Ahmad \& Hjh Masnoorani bt Hj Mohiddin, 2016. The State Obligations and Torture: A Comparative Jurisprudential Analysis. [2016] 2 MLJ clxvii page 2 .

UN Office of the High Commissioner for Human Rights (OHCHR), Preventing Torture: An Operational Guide for National Human Rights Institutions, May 2011, HR/ PUB/10/1. Accessible at: https://www.refworld.org/ docid/4e71ceff2.html, pg. 12.

9 The Committee against Torture views that Article 1 encompasses abuse committed by non-State or private actors if public officials knew or have reasonable ground to believe that an act of torture are being committed and they failed to exercise due diligence to prevent, investigate, prosecute and pun- 
ish such act. See CAT General Comment No. 2 Implementation of Article 2 by States Parties, CAT/C/ $\mathrm{GC} / 22008$.

10 UN Office of the High Commissioner for Human Rights (OHCHR), Preventing Torture: An Operational Guide for National Human Rights Institutions, May 2011, HR/ PUB/10/1. Accessible at: https://www.refworld.org/ docid/4e71ceff2.html, pg 13 .

11 Nigel Rodley and Matt Pollard, 2006. Criminalisation of Torture: State Obligations under the United Nations Convention against Torture and Cruel, Inhuman, Degrading Treatment and Punishment. 2006 EHRLH 115, pg. 28.

12 CAT, 2008. General Comment 2. CAT/C/GC/2 2008, paragraph 5 .

13 Ireland v. United Kingdom, App. No 5310/71, ECHR (Series A) No 25, Judgement of 18 January 1978, pg. 162.

14 Public Committee against Torture in Israel v. the Government of Israel, HCJ 769/02 2006.

15 UN Office of the High Commissioner for Human Rights (OHCHR), Preventing Torture: An Operational Guide for National Human Rights Institutions, May 2011, HR/ PUB/10/1. Accessible at: https://www.refworld.org/ docid/4e71 ceff2.html, pg 14 .

16 "A right that, at least in theory, cannot be taken away or compromised. In human rights conventions certain rights have been considered so important that they are non-derogable: the right to life, the right to be free from torture and other inhumane or degrading treatment or punishment, the right to be free from slavery or servitude, and the right to be free from retroactive application of penal laws." Retrieved from UNTERM. Non-derogable right. Accessible at https://unterm.un.org/ unterm/Display/record/UNHQ/non-derogable_right/D4DBB9694E5B40DA8525751B0077E882 (9 January 2020).

17 CAT, 2008. General Comment 2. CAT/C/GC/2 2008, paragraph 1.

18 CAT, 2008. General Comment 2. CAT/C/GC/2 2008, paragraph 8 .

19 UN Office of the High Commissioner for Human Rights (OHCHR), Preventing Torture: An Operational Guide for National Human Rights Institutions, May 2011, HR/ PUB/10/1. Accessible at: https://www.refworld.org/ docid/4e71 ceff2.html (15 January 2021), pg 19.

20 CAT, 2008. General Comment 2. CAT/C/GC/2 2008, paragraph 3.

21 David Weissbrodt \& Cheryl Heilman, 2011. Defining Torture and Cruel, Inhuman, and Degrading Treatment. Scholarship Repository, University of Minnesota Law School, pages 376-377.

22 David Weissbrodt \& Cheryl Heilman, 2011. Defining Torture and Cruel, Inhuman, and Degrading Treatment. Scholarship Repository, University of Minnesota Law School, pages 377-378.

23 David Weissbrodt \& Cheryl Heilman, 2011. Defining Torture and Cruel, Inhuman, and Degrading Treatment. Scholarship Repository, University of Minnesota Law School, pages 383 .

24 European Court of Human Rights (ECtHR). Ireland v. United Kingdom, App. No 5310/71, ECHR (Series A) No 25 , Judgement of 18 January 1978, pg. 162. See also ECtHR, Selmouni v. France, App. No 25803/94, ECHR 1999-V, Judgement of 28 July 1999, pg. 160.
David Weissbrodt \& Cheryl Heilman, 2011. Defining Torture and Cruel, Inhuman, and Degrading Treatment. Scholarship Repository, University of Minnesota Law School, pages 386 .

26 CAT, 2008. General Comment 2. CAT/C/GC/2 2008, paragraph 9

27 CAT, Concluding Observations on Germany (12 December 2011) UN Doc. CAT/C/DEU/CO/5, pg. 9.

28 David Weissbrodt \& Cheryl Heilman, 2011. Defining Torture and Cruel, Inhuman, and Degrading Treatment. Scholarship Repository, University of Minnesota Law School, pages 391 .

29 Lene Wendland, 2002. A Handbook on States Obligations under the UN Convention against Torture. Association for the Prevention of Torture, page 15.

30 Mohamed Hanipa Maidin, 2019. Opening Address, Regional Dialogue on Malaysia's Accession to UNCAT. 8 July 2019, paragraph 14.

31 Article 1 UN Charter.

32 When UDHR was adopted on 10 December 1948, Malaysia was not yet a member of the General Assembly.

33 Mohamed Hanipa Maidin, 2019. Opening Address, Regional Dialogue on Malaysia's Accession to UNCAT. 8 July 2019, paragraph 15 .

34 Section 331 of the Penal Code if the torturous act causes grievous hurt.

35 Section 331 of the Penal Code if the torturous act causes grievous hurt.

36 Illustrations (a) and (b) Section 330 of the Penal Code.

37 CAT, 2008. General Comment 2. CAT/C/GC/2 2008, paragraph 11.

38 Concluding Observations on Turkey, UN Doc. CAT/C/ $\mathrm{CR} / 30 / 5$, 2003, paragraph 4; Concluding Observations on Kyrgyzstan, UN Doc. A/55/44, 2000, paragraph 75(g); Concluding Observations on Japan, UN Doc. CAT/C/ $\mathrm{JPN} / \mathrm{CO} / 1,2007$, paragraph 20; Association for the Prevention of Torture (APT) and Center for Justice and International Law (CEJIL), 2008. Torture in International Law: A Guide to Jurisprudence. Page 34.

39 Concluding Observations on the United States of America, UN Doc. A/61/44, 2006, paragraph 37(31).

40 Association for the Prevention of Torture (APT) and Center for Justice and International Law (CEJIL), 2008. Torture in International Law: A Guide to Jurisprudence. Pages 35-36.

41 Concluding Observations on Saudi Arabia, UN Doc. $\mathrm{CAT} / \mathrm{C} / \mathrm{CR} / 28 / 5,2002$, paragraph $8(\mathrm{~b})$.

42 Concluding Observations on South Africa, UN Doc. $\mathrm{CAT} / \mathrm{C} / \mathrm{ZAF} / \mathrm{CO} / 1,2006$, paragraph 25; Association for the Prevention of Torture (APT) and Center for Justice and International Law (CEJIL), 2008. Torture in International Law: A guide to Jurisprudence. Pages 37-38.

43 Mohamed Hanipa Maidin, 2019. Opening Address, Regional Dialogue on Malaysia's Accession to UNCAT. 8 July 2019.

\section{REFERENCES}

Association for the Prevention of Torture (APT) and Center for Justice and International Law (CEJIL), 2008. Torture in International Law: A guide to 
Jurisprudence. APT \& CEJIL: Switzerland \& Washington DC.

Convention Against Torture and Other Cruel, Inhuman or Degrading Treatment or Punishment General Comment No. 2 Implementation of article 2 by States Parties. CAT/C/GC/2 2008.

Convention against Torture and Other Cruel, Inhuman or Degrading Treatment or Punishment 1985.

Concluding Observations on Turkey, UN Doc. CAT/C/ $\mathrm{CR} / 30 / 5,2003$.

Concluding Observations on Kyrgyzstan, UN Doc. A/55/44, 2000.

Concluding Observations on Japan, UN Doc. CAT/C/ JPN/CO/1, 2007.

Concluding Observations on the United States of America, UN Doc. A/61/44, 2006.

Concluding Observations on Saudi Arabia, UN Doc. CAT/C/CR/28/5, 2002.

Concluding Observations on South Africa, UN Doc. $\mathrm{CAT} / \mathrm{C} / \mathrm{ZAF} / \mathrm{CO} / 1,2006$.

Concluding Observations on Germany, UN Doc. CAT/C/ $\mathrm{DEU} / \mathrm{CO} / 5,2011$.

International Covenant on Civil and Political Rights 1966.

Juraimi bin Husin v Lembaga Pengampunan Negeri Pahang \& Ors [2001] 3 MLJ 458.

Lene Wendland, 2002. A Handbook on States Obligations under the UN Convention against Torture. Association for the Prevention of Torture. APT: Geneva.

Lilienthal, G. Nehaluddin Ahmad \& Masnoorani ohiddin. 2016. The State Obligations and Torture: A Comparative Jurisprudential Analysis. [2016] 2 MLJ clxvii.

Malaysia's Penal Code.

Manirajan Ramasamy. 2019. No rush, govt says on ratifying UN treaty against torture. https://www. freemalaysiatoday.com/category/nation/2019/07/ 08/no-rush-govt-says-on-ratifying-un-treatyagainst-torture/ (25 November 2019).

Opening Address by YB Mohamed Hanipa Maidin, the Deputy Minister in the Prime Minister's Department at the Regional Dialogue on Malaysia's Accession to the United Nations Convention against Torture and other Cruel, Inhuman or Degrading Treatment or Punishment (UNCAT) 8 July 2019. Accessible at http://www.bheuu.gov. my/pdf/ucapan/TEKS\%20UCAPAN\%20YBTM/ U c a p an $\% 20$ Y B T M \% 20 - \% 20 UNCAT.pdf (10 January 2021).

Report on the Round Table Discussion (RTD) on the Convention against Torture and Other Cruel,
Inhuman or Degrading Treatment or Punishment (CAT), SUHAKAM, Legacy Press, 17 November 2011.

Rodley, N. and Pollard, M. 2006. Criminalisation of torture: State obligations under the United Nations Convention against torture and cruel, inhuman, degrading treatment and punishment 2006. EHRLH 115: 28.

Secretariat, Convention against Torture Initiative. Convention against Torture and Other Cruel, Inhuman or Degrading Treatment or Punishment and Optional Protocol to the Convention against Torture and other Cruel, Inhuman or Degrading Treatment or Punishment. A/RES/57/199.

The Malaysian Bar. Joint Press Statement The Malaysian Government Must Accede to the UN Convention Against Torture. Accessible at https:// www.malaysianbar.org.my/press_statements/joint_ press_statement_\%7c_the_malaysian_government _must_accede_to_the_un_convention_against torture.

Universal Declaration of Human Rights 1948.

United Nations Treaty Collection. Status of Treaties. Convention against Torture and Other Cruel, Inhuman or Degrading Treatment or Punishment. Accessible at https://treaties.un.org/Pages/ViewDetails.aspx?src=TREATY\&mtdsg_no=IV9\&chapter $=4 \&$ clang=_en (7 January 2020).

UNTERM. Non-derogable right. https://unterm.un. org/unterm/Display/record/UNHQ/non-derogable right/D4DBB9694E5B40DA8525751B0077E882 (9 January 2020).

UN Office of the High Commissioner for Human Rights (OHCHR), Preventing Torture: An Operational Guide for National Human Rights Institutions, May 2011, HR/PUB/10/1. Accessible at: https://www.refworld.org/docid/4e 71 ceff2. html (15 January 2021).

Weissbrodt, D. \& Heilman, C. 2011. Defining Torture and Cruel, Inhuman, and Degrading Treatment. Scholarship Repository, University of Minnesota Law School. (2011) 29 Law and Inequality 343.

Anati Binti Kisahi

Legal Associate

Gani Patail Chambers

Kuala Lumpur

Email: anati@gpchambers.legal

Rohaida Nordin (corresponding author)

Faculty of Law

Universiti Kebangsaan Malaysia

Bangi, Selangor

Email: rohaidanordin@ukm.edu.my 